\title{
KELL-E NEKÜNK ÉRDEKEGYEZTETÉS?
}

Jelen cikk célja az érdekegyeztetés szükségességét, esetleg kölcsönös hasznosságát is meghatározó tényezők vizsgálata az elmélettől kezdve (Michigan- és Harvard-modellek, alkalmazotti vagy munkaügyi kapcsolatok), a munkaerő-piaci szegmentáción át az emberierőforrás-menedzsmentben és a versenyképesség alakításában betöltött lehetséges szerepéig. $\mathrm{A}$ szerzők bemutatják a gazdasági világválságnak a kollektív szerződéses lefedettségre és a szakszervezeti szervezettségre gyakorolt hatását is.

Az elméleti logikai építkezés végén az érdekegyeztetés erőterét és a működését befolyásoló elemeket azonosítják hat megállapítás köré csoportosítva. Fontosnak tartják kiemelni, hogy meglátásuk szerint az érdekegyeztetés partneri rendszere minden érdekelt számára magasabb hasznosságot jelent, mint a másik oldal ellenfélként történő kezelése.

Kulcsszavak: érdekegyeztetés, alkalmazotti kapcsolatok, munkaügyi kapcsolatok, Michigan- és Harvard-modell

$\mathrm{N}$ em könnyü olyan kérdésről cikket írni és előadást tartani, amikor az író/előadó is tudja, hogy az olvasók/hallgatók is ismerik nagyjából mind a tényeket, mind az elméleti közelítéseket, vagyis ebben nem igazán fog újat mondani. A következtetésekre is egyetértően bólogatnak majd, igen, kellene változtatni, aztán felállnak és minden megy tovább ugyanúgy, mintha mi sem történt volna.

\section{A Michigan- és a Harvard-modell}

Az új Emberi erőforrás menedzsment kézikönyv okkal tulajdonít kiemelt jelentőséget két, még az előző században megjelent koncepciónak, az ún. Michigan-és a Harvard-modellnek (Karoliny - Poór, 2017, 36-39. o., lásd továbbá Price, 2011). Az alapvetö különbség az, hogy a Michigan-modell a tulajdonosokat, befektetőket állítja az EEM (emberierőforrás-menedzsment) fókuszába, míg a Harvard-modell ebbe az érintettek széles körének (tulajdonos, vonalbeli vezetés, alkalmazottak és csoportjaik, szakszervezetek, kormányzat, közösségek) érdekeit és szempontjait is bevonja. A publikálása óta eltelt 30 évben inkább a Michigan-modell, az üzleti stratégia és a menedzsment szempontjai érvényesültek, majd a 2008as válság nyomán keletkezett kihívásokra reagálva jelent meg erőteljesebben a Harvard-modell. Ez azért azt sugallja, hogy az EEM minden bizonnyal komfortosabban érzi magát a Michigan-modellben, de a Harvard-modellnek lehet valami olyan addicionális ereje, amely miatt szükség esetén hajlandó váltani. Maga a kézikönyv pedig - szakmai vitákat követően - elvi álláspontként kötelezte el magát a Harvard-modell mellett.

Ez már akkor is komoly lépés, ha nem hozza magával azonnal a szemléletváltást minden érintettben és minden funkcióban. (Magában a kézikönyvben is az egyes funkciók kifejtése során - az érdekegyeztetéses fejezeten kívül - csak két kisebb bekezdésben jelenik meg az egyeztetés vagy a munkaügyi kapcsolatok fogalma.)

\section{„Alkalmazotti” vagy „munkaügyi” kapcsolatok}

A két fogalom (és gyakorlat) között megítélésünk szerint az az alapvető különbség, hogy a munkavállalói érdekek ténylegesen milyen súlyt (és képviseletet), alkupozíciót (Bakacsi, 2017) kapnak, érdekbeszámítás vagy valós érdekegyeztetés történik, a folyamat lényege a feszültségek levezetése, vagy kompromisszum/konszenzus-keresés (Karoliny, 2009; László, 2010; Szőts-Kovács, 2006).

1. ábra

A munkaügyi kapcsolatok (balra) és az alkalmazotti kapcsolatok rendszere (jobbra)
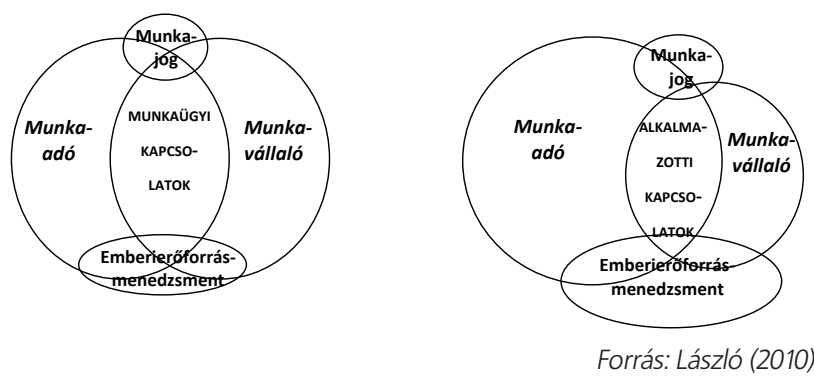

A munkaügyi kapcsolatok rendszere a kollektiv munkavállalói érdekek formalizált-intézményes egyeztetési mechanizmusát jelenti. Ezért is (legalábbis munkavállalói oldalon) feltételezi a kollektív érdekeket képviselő érdekszervezet (szakszervezet, üzemi tanács) megjelenését, mert ezzel a szerveződéssel kínál esélyt a munkavállalói oldalnak arra, hogy a másik fél eröfölényét ellensúlyozni legyen képes. Ebben az esetben legalább elvi szinten egyenlőek az egyeztetés résztvevői, a vállalatvezetés és a munkavállalói képviselet kölcsönösen partnernek tekinti egymást, közöttük valódi, érdemi párbeszéd és tárgyalás zajlik. Az emberierőforrás-menedzsment „,csak” kiszolgálja a feleket, a kereteket működteti, illetve elősegíti a 
tárgyalások sikeres lebonyolítását, valamint biztosítja az elfogadott elemek megvalósulását. (1. ábra)

Az alkalmazotti kapcsolatok alapvetően az emberieröforrás-menedzsment oldaláról közelítik a munkaadó és a munkavállaló kapcsolatát. Meg akarják nyerni a munkavállalókat a vállalati céloknak, és tudják, hogy ehhez figyelembe kell venni a munkavállalók érdekeit, véleményét, de megtartják maguknak azt a jogot, hogy ennek módját és mértékét meghatározzák. Mérlegelik a munkavállalói érdekeket az öket érintö döntésekben, de azt már nem szeretnék, ha ennek során ütközni kellene egy tényleges érdekképviselettel (hiszen esetleg a szakszervezet érvényesítené a saját erejét, és további egyeztetéseket kezdeményezne), a vezetésnek a saját érdekbeszámítását kontrollálnia kellene a munkavállalók valós érdek- és értékítéletével. (Ezért a modell eredeti hívei szerint nincs is szükség szakszervezetekre.) Ebben a kontextusban az emberierőforrás-menedzsment szerepe sokkal hangsúlyosabbá válik. A munkaügyi kapcsolatoknál megvalósuló technikai feladatkör helyett a munkaadó érdekeit szolgálja ki teljes egészében. Célja az esetleges elégedetlenségi pontok feltárása, a megfelelő időben és mértékben történő fellépés és a munkaadó érdekeinek átvitele a munkavállalókra. A munkaadó végrehajtó szervezeti egységévé válik, ezáltal az érdekegyeztetés lehetőségeit még a kezdeményezések előtt szünteti meg.

Teszi ezt annak ellenére, hogy egy együttműködő szakszervezet üzleti partner (Stuart, 1993) és válságmenedzser lehet maga is, az ignorált szakszervezet pedig szükségszerűen, és a szereposztásból eleve adódóan nem is lehet más, mint szembenálló fél. Jó példa erre a német Bündnis für Arbeit is, amelynek keretében pl. a Volkswagennél már sok évvel ezelött kötött a munkáltató és az ágazati szakszervezet olyan megállapodást, amelyben a munkaidő-csökkentés és egy (többé-kevésbé kölcsönös) jövedelmi áldozat fejében a munkáltató foglalkoztatási garanciákat is vállalt (László, 1996). Másfelől annak eldöntése, hogy szükség van-e a két érdek szervezett, tényleges, nyílt egyeztetésére, a munkavállalói érdekek figyelembevételére, nyilvánvalóan helyzet és mérlegelés kérdése. Peter Drucker a következő címet adta egyik cikkének: „Nem alkalmazottak, hanem emberek" (Drucker, 2003), bár a vállalati gyakorlat gyakran nem ezt az elvet követi. Úgy véljük, hogy a bemutatott Harvard- és Michigan-modell kontextusában a Michigan az alkalmazotti, míg a Harvard-megközelítés a munkaügyi kapcsolatoknak feleltethető meg. Másrészt komolyan gondoljuk, hogy a profitcélok és a munkavállalói érdekek nem jelentenek egymást kizáró tényezőket (László, 2002).

\section{Az érdekegyeztetés gyakorlata, változásai a válságot követően}

Annak kiderítésére, hogy a szakszervezetek, a munkaügyi kapcsolatok a gyakorlatban milyen súllyal jelennek meg, az ILOSTAT adatai alapján vizsgáltuk meg az egyes (európai és Európán kívüli) országokat a szakszervezeti szervezettség mértéke, valamint a kollektív szerződéses lefedettség szerint. A válságnál és az arra adott reakciók- nál éltünk azzal a feltételezéssel, hogy az egyes országok sajátosságaiból adódó különbségek mentén eltérő megoldásokat fogunk találni. Több időpontot helyeztünk az elemzés fókuszába (2006, 2008, 2013), és úgy találtuk, hogy jelentös átalakulás nem történt, azaz jellemzöen minimális eltolódások azonosithatók (amelyek az adatfelvétel jellegéből adódó kilengések is lehetnek). Ebből adódóan strukturálisan nem módosultak az egyes országok jellemzői (például nem léptek nagyobb kategóriát általánosságban véve). (2. ábra)

Jól láthatóan azonosítható több csoport, amely kategorizálás számos tényezőre (pl.: munkaerő-piaci sajátosságok, kulturális egyediségek) visszavezethető. Jelen keretek között csak a deskriptív megközelítésre limitáljuk magunkat. Egyrészt általános az alacsony mértékű szervezettség, igaz, hogy ez alól az észak-európai országok csoportosan jelentenek kivételt. Másrészt az országok egy részében a szervezettség és a lefedettség együtt fut (alacsony-alacsony), de van alacsony-közepes szegmens is, és vannak országok, ahol az alacsony szervezettség ellenére magas a lefedettség, mert a partnerek közösen akarják a kiterjesztést, van erre irányuló kormányzati és társadalmi támogatottság is.

2. ábra
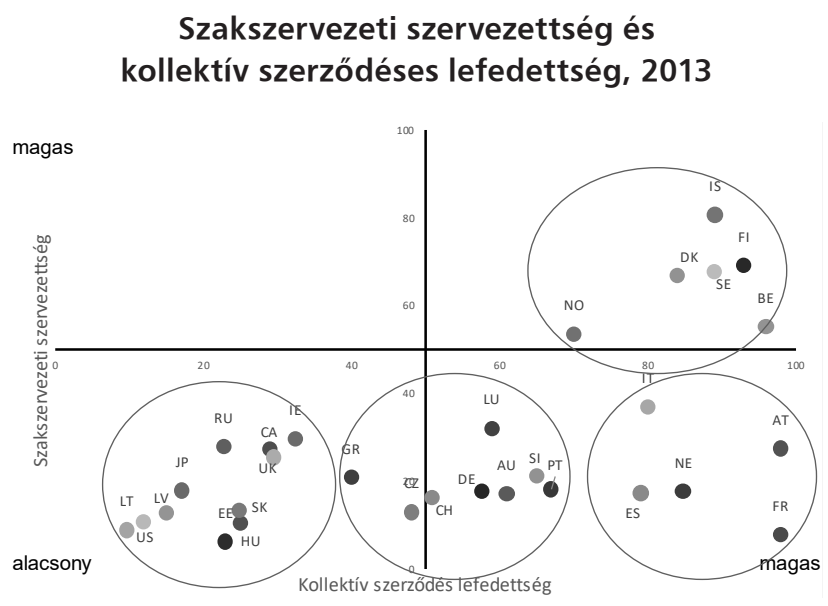

Forrás: saját szerkesztés ILOSTAT adatok alapján

Mindemellett érdemes kiemelni, hogy a válság kezelésénél jól elkülöníthető válaszok azonosíthatók, amelyek több esetben követik a bemutatott csoportosítást is.

Portugália, Románia, Szlovénia, Szlovákia, Görögország és Magyarország esetében a kollektív szerződés általi lefedettség jelentősen visszaesik (2008-2013 között rendre $82-67 \%$, 98-35\%, 92-65\%, 40-25\%, 85-40\%, 36-25\%), ez egyértelmüen mutatja a kormányzati beavatkozást, valamint azt is, hogy a keleti országok esetében közvetlenebb befolyást lehet még alkalmazni a szakszervezetek erejének változtatása érdekében. A másik oldalról, azaz a szakszervezeti szervezettség felől megközelítve ilyen látványos eltolódás nem azonosítható országonként az abszolút értékeket tekintve. Relatív szempontokat figyelembe véve ugyanakkor megállapítható, hogy éppen a kollektív szerződés általi lefedettségben azonosított erőteljes visszaesésben érintett országoknál jellemzően alacsonyabb is a szakszervezeti 
szervezettség. Ebből adódóan az 5\%-os csökkenés jelentősnek minősíthető, ami szintén alátámasztja a térségben történő negatív elmozdulást az érdekegyeztetés területén.

A munkaügyi kapcsolatoknál azonosítható változásokat két eurofundos tanulmány segítségével is érzékeltetjük (Broughton - Welz, 2013; Sweeney et al., 2011). A gazdasági világválság európai begyürüzése eltérően érintette az egyes országokat, valamint időben némileg késlekedve érzödött a hatása. A kormányzatok részéről két fó válaszirány figyelhetö meg: egyrészt a nagyobb mértékü költekezés, a kieső piaci megrendelések állami pótlása, másrészt a takarékosság, a kiadások csökkentése. Ez utóbbi részét képezik a szociális költségek visszafogása, az állami szektorban a fizetések csökkentése (pl. Görögország, Írország, Románia, Spanyolország), vagy legalább befagyasztása (pl. Ciprus, Lengyelország, Nagy-Britannia, Portugália), a nyugdíjak növelésének elhalasztása, illetve a részmunkaidő (2009-2010 között 0,4-1,2\%-os növekedés jellemzően) vagy más atipikus munkaformák (határozott idejü foglalkoztatás 2009-2010 között 0,52,5\%-os növekedés) bevezetése, támogatása.

Ezzel párhuzamosan a szociális partnereknek a kapcsolódó törvénykezésbe történő bevonása általánosságban nézve csökkent, többször a megkezdett egyeztetésekböl kizárták a szakszervezeteket annak érdekében, hogy a gazdasági oldalról szükségesnek ítélt lépéseket meghozzák. Előtérbe került a rugalmasság kérdésköre, jellemzően olyan intézkedéseket léptettek életbe, amelyik a munkaadó részére növelte a mozgásteret (Görögországban például vállalati szinten lehetővé vált a szektorális megállapodástól történő derogáció, Portugáliában felbonthatta a munkáltató a kollektív szerződést), valamint az eddig jellemzően nemzeti szintű megállapodások is elmozdultak az ágazati tárgyalások felé (pl. Finnország, Svédország).

Összességében a szociális partnerség helyzetének a válság miatt bekövetkező változását tekintve a 28 EU-országból 11-nél játszott jelentős szerepet az Európai Unió oldaláról érkező elvárás, 18-nál a nemzeti szintű válaszreakció és 11-nél a szociális partnerek általi kezdeményezés. Árnyalja a képet, ha megnézzük ország szinten a három elem megjelenési gyakoriságát. A 28 országból 8-nál semmi nem jelent meg befolyásolóként, 4 esetben egy tényező (kiemelkedő Görögország, ahol komoly átalakításokat kellett vállalni az EU pénzügyi csomag folyósításáért), 12 tagállamnál két elem, és összesen 4 országban mindhárom oldal erőteljesen fejtette ki a hatását. Ez azt jelenti, hogy ha az egyik oldalra megfelelő reakciót alakítanak ki, akkor jellemzően megjelenik legalább egy másik elem is. Egy hatást sem tartottak jelentősnek Ausztria, Csehország, Dánia, Franciaország, Lengyelország, Málta, Norvégia és Svédország esetében. Ezekben az országokban jellemzően magas a kollektív szerződés általi lefedettség (Lengyelország kivételével mindenhol 50\%-os vagy lényegesen magasabb, átlagosan 70\%-os szintü) (Broughton - Welz, 2013).

A konkrét intézkedések kategóriái:

- kollektív szerződés decentralizációja: Görögország, Litvánia, Olaszország, Portugália, Románia, Spanyolország, Szlovákia,
- munkabér-megállapítási folyamatok: Csehország, Egyesült Királyság, Görögország, Franciaország, Írország, Lettország, Magyarország, Portugália, Szlovénia,

- munkabéremeléshez kapcsolódó folyamatok: Belgium, Ciprus, Spanyolország, Luxemburg, Málta,

- állami szektorban bérbefagyasztás: Ciprus, Egyesült Királyság, Írország, Lengyelország, Magyarország, Olaszország, Szlovákia,

- állami szektorban bércsökkentés: Ciprus, Írország, Lettország, Litvánia, Olaszország, Románia, Szlovénia,

- jóléti kiadások csökkentése és nyugdíjintézkedések: Ciprus, Dánia, Franciaország, Írország, Lengyelország, Lettország, Románia, Szlovákia,

- foglalkoztatási intézkedések: Görögország, Hollandia, Nagy-Britannia, Németország.

A válságnak a munkaerő-piaci kapcsolatokra kifejtett hatása:

- az állami intézmények és érdekérvényesítésben részt vevő szereplők hatáskörének átszervezése: Írország, Luxemburg, Magyarország, Románia,

- szakszervezeti szervezettségben bekövetkezett viszszaesés: Ciprus, Bulgária, Észtország, Lettország, Litvánia, Nagy-Britannia, Németország, Svédország, Szlovákia, Szlovénia,

- csökkenő befolyás és láthatóság: Belgium, Hollandia, Írország, Litvánia, Magyarország, Németország,

- a szociális partnerek közötti interakció erősödése: Hollandia, Litvánia, Magyarország, Németország,

- új szociális partnerségi modell: Görögország, Spanyolország, Szlovénia.

\section{Érdekegyeztetés a HR szintjén}

\section{Az emberi tőke szerepe az emberierőforrás- menedzsmentben}

A már említett Emberi erőforrás menedzsment kézikönyv abból indul ki, hogy az emberekkel kapcsolatos mérlegelések és döntések során a munkatársakat a szervezet egyik legfontosabb vagyontárgyaként, tőkeelemként kell figyelembe venni. Ebben a munkatársi dimenzióban a cég értékét meghatározó tőkeelemek közé tartozik az emberi vagy humán tőke (képesség, kompetenciapotenciál), illetve a közösségi vagy társas tőke (együttmüködés, szervezeti kapcsolatrendszer, a potenciál hasznosulása) (Karoliny - Poór, 2017, 24-26. o.). Más oldalról közelítve ugyanezt mondja az ott idézett AMO-modell is (Appelbaum et al., 2000; Boxall - Purcell, 2003; Juan - Juan, 2016): a teljesítményt a megfelelő képességek (A), a teljesítéshez szükséges motiváció $(\mathrm{M})$ és a teljesítés lehetősége, feltételeinek biztosítása $(\mathrm{O})$ együttesen határozza meg. Így az EEM müködésének eredménye a megfelelö jellemzőkkel rendelkező munkaerő-állomány (humán tőke) és az egyéni és szervezeti alkalmazotti magatartás (társas tőke): létrejön a szükséges teljesítmény, elkötelezettség, együttmüködés és bizalomszint, amelynek outputja nemcsak a szervezet 
kifelé felmutatható eredményessége, hanem a szervezeten belül - többek között - az érintetti csoportok kulcsszegmensei közötti kölcsönös elkötelezödés (Karoliny - Poór, 2017, 27-31. o.).

Témánk szempontjából a fentiekből muszáj kiemelnünk azt, hogy az „A” (a képesség, a humán tőke) nem kevesebb, de nem is több az EEM számára, mint egy szükséges, de nem elégséges feltétel. Ráadásul az „M” és az „O” ennek megszerzési lehetőségét is befolyásolja azon keresztül, hogy a vállalati belső munkaerőpiacon kialakult vélemény a szájmarketing útján erősen alakítja a vállalat külső munkaerő-piaci pozícióját is. Az ,alapfeltétel $A$ " mellett ezért tartjuk fontosnak, kiemelendőnek a „meghatározó $M$ ”'-et.

Nem újdonság, hogy a motiváció (és pláne annak olyan magas szintje, mint a kölcsönös bizalom, lásd Bácsi, 2017) két különböző úton, kapcsolatrendszerben alakulhat ki: egy „külsö” szerzödéssel (amelyben kényszer és/vagy érdek jelenik meg, de ez nem eredményez belső azonosulást), vagy egy „,belső” szerződéssel (amelyet szándék, érzés és érdek határoz meg, ezért is belső azonosulást vált ki) (Kuvaas et al., 2016). Ezek teljesen függetlenek a hivatalos dokumentumoktól. Lehet, hogy egy „,szerződés” a foglalkoztatás teljes ideje alatt megmarad külsőnek, de az is lehet, hogy idővel eltünik a külső, és átadja helyét egy belsőnek.

A külső szerződést eredményező kényszerhatást kiválthatja az adott munkaerö-piaci helyzet, és abban az adott személy pozíciója is. Például amennyiben nincs választási lehetőség, mert nincs más munkahely, nincs más jövedelemszerzési alternatíva, vagy elvileg lenne, de ténylegesen nem elérhető, mert a belső munkaerőpiac erős védelme miatt nem lehet betörni az adott szegmensbe. A kényszerítő hatás kialakulhat a belső munkaeröpiacon is, amelyet többnyire a munkáltató hatalmi pozíciójának minden mást kizáró megnyilvánulásai, a belső hierarchikus/utasításos rendszerek váltanak ki.

Paradoxonnak tűnik, de a kényszereffektus igen gyakran nem jelenik meg a felszínen, azt egyéni érdekké alakítja magában az adott munkavállaló, mert belátja, hogy a személyes/családi szükségletei kielégítése csak az adott szituációhoz való alkalmazkodással valósítható meg. Az is lehetséges, hogy az érdek kényszer nélkül jelenik meg a külső szerződésben, ha pl. a munkahely ennek teljesen megfelelő ellenszolgáltatásokat kínál. A külső szerződések közös vonása ezzel együtt is az, hogy a kapcsolat nem válik elkötelezettséggé, addig és annyira él, ameddig és ahogyan a nyomás vagy az érdekek kielégítése érvényesül.

Belsővé két ágon válhat a kapcsolat (bár ezek nem teljesen függetlenek egymástól). Egyrészt akkor alakul így, amikor olyan erőssé válik a motiváció, hogy a munkatársnak már olyannyira érdeke lesz egy adott teljesítmény vagy magatartás, hogy azonosul is azzal, elköteleződik mellette (belső érdekeltségi rendszerek, önállóság, megbecsülés, munkafeltételek). A másik ág a stílust, a kultúrát, a kapcsolati formákat emeli ki, és kifejezetten a szubjektiv, akarati tényezőkre épít (Meyer et al., 2004). Például lehet, hogy egy cégnél most kisebb a béremelés, de ha nyílt a helyzetelemzés és a stratégiaépítés, ha folyamatos és érdemi a kommunikáció lefelé és felfelé is, ha kialakul a „mi”-tudat, ugyancsak létrejöhet az elköteleződés. Avagy lehet, hogy a kollektív tárgyalás végén a munkavállalók nem érték el azt a béremelést, amit reálisan elvárhatónak gondoltak, de ezzel is elégedettek lesznek, ha partneri volt a tárgyalás stílusa, levezetése, átélték annak korrekt és szakszerü folyamatát, átérezték annak méltánylandó kereteit.

\section{A belső munkaerőpiacok szegmentáltsága}

A már korábban említett emberi tőkével kapcsolatban a kézikönyv azt a „szükítő” tézist is megfogalmazza, hogy a versenyelőnyt ezen belül azok szerezhetik meg, akik ritka, utánozhatatlan, ill. helyettesíthetetlen kompetenciákkal rendelkeznek, illeszkednek a szervezet elvárásaihoz. Vagyis a foglalkoztatottaknak csak egy része az, amelyik humán tőkének is tekinthető: van tőkeértékkel rendelkező és van ilyennel nem rendelkező munkavállalónk. Lényegében ezzel (is) elindul egy belső munkaerö-piaci szegmentálás: kik a fontosak és kik nem ${ }^{1}$.

A szegmentált munkaerőpiacok elmélete természetesen nem új (Lever-Tracy, 1983; Peck, 1989). A munkaerö-piaci szegmensek kialakulása egyrészt szükségszerü, mert a munkaerőpiac müködésének természetszerü következménye: az árak/bérek a kereslet/kínálati viszonyokhoz, az értékteremtés színvonalához igazodnak (bár ezek mobil szegmensek), vagy a verseny- és közszféra eltérő sajátosságai miatt alakulnak ki. Másrészt többé-kevésbé természetesnek tekinthető, hogy a kedvező helyzetbe kerülő „elit” tagjai védik a saját pozíciójukat, igyekeznek azt elzárni a verseny, a versenytársak elől. Harmadrészt abból a racionális EEM-megfontolásból épül, hogy ha nem kell mindenkit magas juttatásban részesíteni, hanem „elég” azt az elit szegmensekre fókuszálni, az jelentős költségmegtakarítást eredményezhet.

Ezen belül viszont nagyon nem közömbös az, hogy mi lesz a belső munkaerö-piaci szegmensek kialakításának elve, feltételrendszere: kik tartoznak majd az elitbe, és hogyan ítélik meg az alsóbb szegmenseket. Ha csak a humán tőkére fókuszálva mondjuk azt, hogy annak tartalma, spezializáltsága, egyedisége joggal indukálhat elit pozíciót, az csak az érem egyik oldala, mert nem vonja be a szegmentációs szempontok közé a társas tőkét. Fontos fel- és elismerni azt, hogy a tökeértéket nemcsak a humán tőke határozza meg, és a belső szegmenseket sem lenne szabad csakis a humán tőke (és a szervezeti rang, pozíció, hierarchia) alapján elhatárolni. A társas tőkéhez másfajta kompetenciák, munkamegosztásbeli szerepek, kapcsolati pozíciók stb. kapcsolódnak, de ezek éppúgy kiemeltté tehetik/teszik azok hordozóit, mint a különleges emberi tőke birtokosait (Botelho, 2017; Donate Sánchez, 2016; Sitar, 2018). Például ha egy adott személy vagy csoport jelentős humántőke-erővel rendelkezik, de csakis saját érdekeiket követi, elit rangja ellenére nem segíti a szervezet folyamatait, eredményességét. Vagy másoknak lehet, hogy gyengébb a humántőke-értékük, de a folyamatokban betöltött kulcsszerepük, terhelhetöségük, elkötelezettségük alapján mégis kiemelt figyelmet érdemelnek. 
Lehet ugyan differenciálni, de végső soron egy szervezet eredményessége, versenyképessége sosem csupán az „elit” emberitőke-szegmensen múlik. Fals megközelítés, hogy elég „csak” a szük elittel belső szerződést kötni, a többiekkel ,jó” a külső szerződés is. Az ,alsóbb” szegmensek ugyanúgy figyelmet, megbecsülést, munkatársi elismertséget érdemelnének az EEM részéről, mint az „elit” tagjai.

\section{Kell-e nekünk érdekegyeztetés a XXI. században?}

Következtetéseink levonásával azt szeretnénk körbejárni a következőkben, hogy - túl az elméleti megfontolásokon - igényelhetjük-e, ajánlhatjuk-e a gyakorlat számára is az érdekegyeztetést. Mit nyerhetünk, és mit veszíthetünk az érdekegyeztetéssel, (amire a válaszok minden bizonnyal szubjektívek és kontextusfüggők, esetleg prekoncepciósak). Mindegyik pontnál úgy véljük, hogy pozitív és negatív elemek is kiemelhetőek, emellett pedig középpontba helyezzük a makro- és mikro-(vállalati) szintek, továbbá az emberierőforrás-menedzsment és az egyén lehetőségeit, gyakorlati megvalósulási formáit.

(1) Első tézisünk azt emeli ki, hogy az érdekegyeztetés (a totális önállósággal és döntési kompetenciával szemben) egészen biztosan hatalommegosztást jelent, ami megítélésünk szerint ugyanakkor nem feltétlen jelenti a hatalom csökkenését is, hanem „,csak” annak átrendezödését. Elöre kell bocsátanunk azt, hogy ez egyaránt érinti az érdekegyeztetés minden résztvevőjét, az eredője pedig mindkét oldalon lehet pozitív is, negatív is, de az eredménye lehet egy win-win pozíció, illetve a klasszikus fogolydilemma keretei közül kiszakadva magasabb közös hasznossági szint elérése is.

Az érdekegyeztetés során a saját korábbi, „,üggetlen” egyéni és szervezeti hatalom egy részét valóban „be kell áldozni” a tárgyalások, egyeztetések, kompromisszumos/ konszenzusos döntések oltárán, mert „,engedni” kell a másik oldalnak. Ezzel párhuzamosan viszont a „hatalom” a megállapodás eredményeként, a partneren keresztül (részben legalább) kiterjed majd a másikfél belsö territóriumára is, hiszen a másik oldal is azt a megállapodást hajtja majd végre, amelyben benne foglaltatnak a saját érdekei, céljai is! A szakszervezet ennek nyomán - közvetve beléphet makroszinten a törvényalkotási folyamatba, mikroszinten az üzleti terv kialakításába és megvalósításába. A kormányzati oldal pedig a tárgyalás eredményeként alakíthatja a szakszervezetek fellépését (a konföderációkon keresztül a vállalati szervezetek hozzáállását is), a munkáltató a szakszervezeteken keresztül alakítani képes a belső információáramlást, élvezheti annak előnyét, hogy a szakszervezet a saját szervezeti rendszerén keresztül érvényesíti majd a megállapodást, alakítja a munkavállalók hozzáállását, mentalitását.

Vagyis nem azt kell nézni, hogy az érdekegyeztetés nyomán kisebb vagy nagyobb lesz az egyik vagy másik fél hatalma, hanem azt, hogy a korábbi hatalom változatlanul, direkt módon, de szükebb hatókörrel (csak a saját tagságra, szervezetre, hatalmi gépezetre vonatkozóan) érvényesüljön, vagy az újtípusú „hatalommegosztás” egy részben legalább megosztott, de egyúttal indirekt módon egy tágabb, új területekre/dimenziókra is kiterjedö, azokat befolyásolni képes hatalomgyakorlást eredményezzen.

Ez megfelel mind a Harvard-modellben megfogalmazottaknak, mind pedig a munkaügyi kapcsolatok egyeztetési tér szellemiségének és müködési szabályainak. Ebből adódóan az EEM feladata a keretek biztosítása, amivel párhuzamosan az egyéni egyeztetés lehetősége csökken, ugyanakkor a közös fellépésen keresztül hosszú távon minden érdekelt csak nyerni fog.

Érdekegyeztetés nélkül tisztán megmarad a vezetés hatalma, ereje, amellyel nagyot nyerhet, de veszíthet is. Az érdekegyeztetéssel a hatalom és az erő megosztódik (látszólag csökken, biztosan átalakul), de megvan az esély a kiterjesztésre is: a szinergia elérésével a hatalom és erő megnőhet, mindkét oldalon.

Ugyanakkor azt is tudjuk, hogy a döntés nem egyszerü, a váltás egyértelmüen kultúra-, stílus-és paradigmaváltást igényel.

(2) Második tézisünk önmagában közhely, mégis muszáj kiemelni: könnyü a másik oldalra hivatkozni, mutogatni, csak ebböl nem lesz semmi. Munkáltatói és szakszervezeti oldalról egyaránt lehetne nyilatkozatokat gyüjteni arról, hogy mi milyen nyitottak és konszenzusra törekvők vagyunk, a másik oldal bezzeg nem együttmüködő, ezért nincs eredménye a tárgyalásnak. Ezt mindkét oldal rendszeresen megteszi: én igen, de te nem; én nem, mert te nem. Tyúk vagy tojás.

Biztosan vitatható az a megjegyzés, hogy ezen belül talán az a munkáltatói oldal van lépéselőnyben, amelyik jelenleg pozícióelőnyt élvezhet. A szakszervezetek számára már a rendszerváltás is eleve a szinte teljes ignorálást hozta, ami többé-kevésbé máig is tart, hol kényszerből, hol számításból, politikai/hatalmi vagy népszerüségi megfontolásokból. Makroszinten egyértelmü eltolódás azonosítható a tényleges érdekegyeztetések háttérbe szorítására, leginkább csak a kormányzati szándékok legitimációja céljából vonják be a szociális partnereket. Egy ilyen környezet és működési modell könnyedén leképeződik a mikro napi müködésre is, azaz a vállalatok is hasonló megoldásokat alkalmaznak. Mindenesetre: ha az egyik (bármelyik) oldal ilyen, abban benne van a másik oldal, és a harmadik is, ilyenné szocializáltuk/szocializálódtunk. Mindezek egyértelműen a Michigan-modell megjelenési formái, azaz az alkalmazotti kapcsolatok egyeztetési keretét helyezik előtérbe. Az egyéni alku lehetősége az adott munkavállaló saját képességeinek függvénye, ami a szegmentált piacok elitista megközelítését támogatja. Ezt nagyon negatívnak tartjuk, azaz úgy véljük, hogy megint csak konszenzus kellene a változtatáshoz, nem lehet elvárni, hogy én majd akkor változok, ha a másik már megváltozott.

Lehet az új Munka Törvénykönyve (Mt.) szerint formális-gyenge, de hatályos kollektív szerződést kötni; lehet sárga szakszervezetet gründolni és támogatni, de a munkavállalók nem buták, látják, hogy mi a pálya, milyen keretek között mozoghatnak. Ne tessék arra hivatkozni, hogy motiválatlanok, müveletlenek, ellenségesek, lus- 
ták, lógósak. Saját mozgásterüket töltik ki, lehetőségeik keretei között érvényesítik saját érdekeiket. Ha nincs esélyegyenlőség, nincs képzés, kultúraközvetítés, mitől lennének mások? Ha nem akarjuk, hogy hangoskodjanak, csendben is maradnak. De ez nem aktivitás, nem belső, hanem „csak” külső szerződés, amiből sosem lesz innováció és versenyképesség, csak a szükséges/kötelező teljesítmény és intenzitás.

Érdemi érdekegyeztetési rendszer akkor épülhet ki, ha a kormányzati oldal megteremti ehhez a szervezeti és működési feltételeket, a mozgásteret, ha a munkáltatói oldal meglátja ebben a versenyelőny-teremtési lehetőséget, ha a szakszervezetek feloldják a szervezeti korlátokat és növelik a felkészültséget, és mindhárom oldal részéről, ha kialakul a partnerség, az együttmüködési készség, megegyezési szándék, a közös-kölcsönös előnyök keresése.

(3) Harmadik tézisünk a korábban kifejtett tőkeszemlélethez, az emberi és társas tőkedimenzióhoz kapcsolódik. Makroszinten a szociális partnerek eltérő profillal, képességekkel, valamint stratégiai szemlélettel rendelkeznek. A kormány számára leginkább a prioritásként azonosított szektorokkal való együttműködés jellemző, ők adják az elit részt, míg a többi szereplő gyengébb érdekérvényesítési lehetőségekkel bír. Korábban amellett érveltünk mikroszinten, hogy létfontosságú a vállalkozás számára az emberi tőke nagysága és szerkezete, színvonala, rendelkezésre állása, de az eredményes/hatékony vállalati működéshez elengedhetetlen - sok más külső és belső tényező mellett, de azoktól nem függetlenül - a társas töke, vagyis az együttmüködés, a bizalom, az elköteleződés, vagyis mindaz, amibe beépülve a humán tőke valóban kreatív lesz, újat alkot, növeli a termelékenységet. Ezért kellene egyrészt a belső szegmentálás során a társas tőke szerepét (is) egyértelmüen érvényesíteni, az azonosulást, elköteleződést, a belső szerződést nemcsak az elitnél elérni mind makro-, mind mikroszinten. Ehhez pedig megítélésünk szerint valódi érdekképviseletek közötti valódi egyeztetés kellene, munkaügyi kapcsolatok építése az alkalmazotti helyett.

A szakszervezetekhez füződő viszony a munkaadók részéről a vállalati kultúra egyik kifejezője. Az, hogy nem kell a szakszervezet, mert esetleg fellépne a munkavállalók érdekében, ezt pedig nem akarom, mert „én vagyok a kiskakas a saját szemétdombon", egyértelmü üzenet a munkavállalóknak: ne ugráljanak. Nem is fognak ugrálni, kis pénz, kis foci. Lehet szegmentálni a belső munkaerőpiacon, kiemelni egyes szegmenseket, akikre lehet támaszkodni, de a többiek tudják, érzik majd, hogy nem fontosak. Nagyon altruistáknak kellene lenniük a munkavállalóknak ahhoz, hogy egyoldalúan elkötelezettek, bizalommal legyenek a munkáltatójuk felé, miközben a munkáltatótól ugyanazt nem kapják meg.

Az elmúlt pár évben - hátunk mögött egy válsággal és együtt élve egy kivándorlási hullámmal (valamint migránsválsággal) - alapvetően megváltoztak a munkaerö-piaci körülmények. Már nem egyszerüsíthető le az EEM toborzási politikája és aktivitása arra, hogy harcolni kell a legjobbakért, és csak „,le kell szólni” az „egyszerü” betanított és szakmunkásokért, mert a hazai piacon is megjelenő kivándorlási nyomás (és a válság után megerősödő külpiaci szívó hatás) miatt nemcsak az elitből van hiány, hanem a kétkezi munkásból is. Az a kör, amelyet eddig a belsö munkaerőpiac perifériájának tekintettük, egyre szükül.

Erre még újabb rétegek rakódnak a hazai munkaerőpiacon. Egyáltalán nem függetlenül a korábban már említett munkaerő-piaci hatalmi viszonyoktól, az elmúlt években nemigen volt akadálya annak, hogy „,fent” elszaladjanak a bérek, „lent” viszont - a verseny- és a közszférában egyaránt - elhalasztódjanak az érdemi béremelések. Amit az érintettek gyenge ellenálló-képessége (kiszolgáltatottság, félelem, gyenge érdekképviselet, a szolidaritás és társadalmi támogatottság hiánya) miatt évekig nem kellett komolyan venni, azt ma már nem lehet elodázni. A munkaerőhiány értelemszerűen megváltoztatja az erőviszonyokat, felerősíti a munkavállalók eddig visszafogott hangját. Erre a növekvő sztrájkaktivitás miatt is muszáj odafigyelnie a versenyszférának is, a költségvetésnek is, hacsak nem akarják végleg elveszíteni a számukra egyre fontosabbá váló munkavállalói rétegeket.

A Cranet-felmérések eredményei (Poór et al., 2018; Poór et al., é.n.) egyértelmüen alátámasztják ennek megjelenési formáit mikroszinten, azaz Kelet-Közép-Európában (de jellemzően az egész világon) a válság esetén előtérbe kerül a kollektív érdek, a szakszervezeti szervezettség erösödése, a szembenállás kialakítása, míg kiszámítható környezetben inkább az egyéni alku, érdekérvényesítés. Ez azt is jelenti, hogy alapvetően a „normál” működési mederben a viszonylagos gazdasági jólét általánosságban negatívan hat az érdekegyeztetés különböző megjelenési formáira, előtérbe kerül a Michigan-modell, és a munkavállalók ezt hagyják is. A válság idején pedig a szervezkedés iránti nagyobb hajlandóság következtében, plusz az érzelmi oldal erőteljesebb megjelenése miatt a Harvard-modellt választják mikroszinten. Ezt támasztja alá az érdekegyeztetés gyakorlata, változásai a válság következtében is, hiszen akkor a kormányok oldaláról érkezik egy negatív irányú válasz (jellemzően Michigan-modell szemléletben), azaz van egy olyan szereplö, akivel szemben érdemes összefogni.

Vagyis a munkaerőpiacok, szakmák, foglalkozási csoportok és formák nagy többségében megváltoztak vagy megváltoznak a pozíciók, az erőviszonyok, a fontossági rangsorok és hiánylisták. Az általunk vázolt elméleti megfontolások és a gyakorlati tapasztalatok egyaránt abba az irányba mutatnak, hogy ehhez igazodva változnia kell az EEM tőkeszemléletének, értékrendjének, külső és belső munkaerő-piaci szegmentációjának, hozzáállásának és módszereinek is - akár tetszik, akár nem, akár egyezik korábbi felfogásával, akár nem.

(4) A hatalmi tényezők sajátos, külön dimenziója a munkajog. Az Mt. legutóbbi, átfogó módosítása bár többek között - a flexicurityre hivatkozik, annak magyar modelljét mégis elég egyoldalúra hangolta: javítja a rugalmasságot a munkáltatók szempontjait érvényesítve, ugyanakkor csökkenti a szakszervezetek jogkörét, erejét, kevesebb biztonságot nyújt a munkavállalóknak, amiben egyértelműen megjelenik a Michigan-modell és az alkalmazotti kapcsolatok müködési keret. Igaz, hogy alap- 
vetően ez a mikroszintű érdekegyeztetést szabályozza, ugyanakkor makroszinten is a tényleges és valós egyeztetés háttérbe szorulását azonosíthatjuk. Ebben a helyzetben érthető az, hogy munkavállalói nézőpontból gyengének, elhanyagolhatónak látszik a szakszervezet (és az üzemi tanács is), míg a munkáltatói oldal, illetve a makroszint ennek előnyeit élvezve nem igazán akarja, hogy ez a helyzet megváltozzon.

Itt azt kellene - munkáltatói oldalról is - mérlegelni, hogy mihez jó ez a jelentős pozíció és mihez nem elég. Kínálna-e a munkáltatónak többletet bármiféle érdemi egyeztetés a szakszervezettel (üzemi tanáccsal). A jog számos esetben nem tud (és nem is akar) részletekig menően szabályozni, a munkaadónak (mikroszinten) és a kormánynak (makroszinten) van lehetősége arra, hogy (ha akar) a másik oldal nagyobb szintű bevonását valósítsa meg az egyeztetési, akár a döntési folyamatokba. A mérlegelés egy sajátos szempontja lehet az, amit a társas tőke jelentősége kapcsán említettünk. Ahhoz, hogy kihozzuk a lehetséges eredményességi maximumot a betanított munkából, egyszerü szakmunkából, a tömegtermelésből, ahhoz ez a megoldás nagyon jó; ahhoz viszont, hogy bevonjuk és megnyerjük a munkatársainkat, a hazai vállalatokat a versenyképesség növeléséhez, egy intelligens gazdaság építéséhez, nem tünik ideális megoldásnak. El kell dönteni, hogy melyik pályán akarunk haladni, és a választott pálya hosszú távon hová vezet.

A jelenlegi jogszabályi környezet inkább a hierarchikus, gazdasági/munkáltatói érdekeknek kedvez. Az előzőek alapján mérlegelés kérdése, hogy melyik jelent több előnyt: ha valaki maximálisan él ezzel a lehetőséggel, vagy azt a kölcsönös előnyök elérésére használja. A munkaerőpiac magasabb dinamikájú rugalmassága - sem a jogi szabályozásban, sem a vállalati gyakorlatban - nem feltétlen zárja ki a flexicurity elvben eredetileg megfogalmazott munkavállalói biztonságot, érdekérvényesítést.

(5) A szakszervezet- (érdekegyeztetés-) politika a gazdaságpolitika/kormánypolitika szerves, integráns része. A gazdasági érdeknek (a gazdaság helyzetbe hozása, a piac építése, tőkemegtérülés, polgárosodás stb.) a társadalmi érdek (jólét, esélyegyenlőség, szociálpolitika, szolidaritás) fölé helyezése azt igényelte, hogy ne legyen ezen a téren sem ellensúly (,ellenhatalom”), amelyik majd a szociális szempontokat hangsúlyozza, így ütközteti is a gazdasági érdekekkel. Ezt láttuk a '90-es években, még a Horn-kormány alatt is, még a TGM kudarcában is.

Újabb időkben pedig ugyanez kellett ahhoz a kimondott/kimondatlan gazdaságpolitikai stratégiához is, hogy a bérek alacsony szinten tartásával ellensúlyozzuk a versenyképesség, termelékenység alacsony szintjét. Legyen vonzó a befektetők számára a viszonylag jó hazai munkaerő, alacsony bérszinttel (és hogy a kormány is jól járjon, viszonylag magas adó- és járulék-elvonással, mert a költségszint még így is kedvező marad a befektetők számára). Ha sok vállalkozásunk normál piaci feltételek mellett nem lenne életképes, segítsük meg őket az alacsony bérekkel, olcsó és kiszolgáltatott, gyenge érdekérvényesítési képességű munkaerővel (valamint a szürke gazdaság mind az ötven árnyalatával).
Ha nem nőtt a versenyképesség, azért a gazdaság is felelős, valamint a gazdaságpolitika is, mert nem a ,,sok pénz, nagy foci”, hanem a „kis pénz, kis foci” politikája érvényesült. Az olcsó tömegmunkának inkább kedvezett (volt rá igény), mint a versenyképes, innovatív, tudásalapú kínálattal és kereslettel jelentkező munkaerőpiacnak, gazdaságnak (lásd 16 éves korhatár, az Mt. módosítása, az oktatás színvonala és feltételrendszere, az életen át tartó tanulás és foglalkoztathatóság alapjainak eliminálása).

Ennek egyenes következménye mind a jövedelemolló nyílása, mind a magasabb bér kielégítetlen igénye, mind az igényesebb feltételek és lehetőségek, normálisabb körülmények keresése a munkavállalók részéről. Ez tömeges (sokszázezres nagyságú) kivándorláshoz, az pedig sok területet jelentősen érintő munkaerőhiányhoz vezetett, miközben a lent hagyott, nem foglalkoztatható, versenyképtelen kompetenciákkal rendelkezők megoldatlan feladatot és terhet jelentenek a foglalkoztatás-, oktatás- és szociálpolitikának. Egyenes következmény, saját farkába harapó kígyó.

Ezek alapján úgy gondoljuk, hogy a Michigan-modell nem tartható fent hosszú távon, hiszen a rövidebb kormányciklusokra optimalizált működési és egyeztetési mechanizmusok biztosíthatják a kormány által elképzelt megoldások megvalósítását, hosszú távon viszont számos negatív következménnyel járnak. Makroszinten (is) a Harvard-modellre való áttérésre van szükség, amelyik az eddig említett, a humán tőkéhez kapcsolódó pozitív elemeket helyezi középpontba, és ezáltal biztosítja az érdekegyeztetés fejlesztését, a gazdaságpolitika intelligens, innovációra épülö, növekedést elérő pályára állítását.

(6) Végkövetkeztetésünk pedig az, hogy mindehhez valódi paradigmaváltás kellene. Nem elég, ha a kormány meghirdeti a NER-t, a valóságban viszont elnyom minden alulról érkező hangot, megszünteti az egyeztetés fórumait. Nem elég, ha híres management-guruk cikkekben, tréningeken új elveket hirdetnek, amitől a hétköznapi gyakorlat többnyire jottányit sem változik. Ha az elméleten fellelkesedve a vállalat fogadó szintjén, a gyárépület bejáratánál nagybetűs feliratok hirdetik a cég társadalmi elkötelezettségét, de ugyanez már nem látható az irodák folyosóiról, az üzemcsarnokon belülről, akkor az kifelé jól mutat, alkalmas az új belépők és a sajtó elvarázsolására, de egy idő után már senkit sem fog megérinteni.

Az EEM-elvek szerint a bér, a személyzeti költség (meg a képzés, a munkakörülmények alakítása stb.) valójában nem folyó költség, hanem hosszabb távú befektetés. Az lenne az érdekegyeztetés, a szakszervezeti politika is, azaz a Harvard-modell és a munkaügyi kapcsolatok melletti elköteleződés a megfelelő válasz. Ha partnernek tekintjük (nem kell szeretni!), akkor emelt fővel jár a bizalmi is, a szakszervezeti tag is. Érzi, hogy fontos, erős, önálló individuum, felnőttként viselkedik. Ha befektetünk a szakszervezetbe, megfelelő feltételeket biztosítunk, képezzük (társadalmi-gazdasági összefüggések, ágazati-piaci helyzetkép, stratégiai szempontok, információ, szakmai-műszaki, informatikai és jogi ismeretek, tárgyalástechnika stb.), akkor művelt, profi érdekképviselőként lehet majd tárgyalni vele, eredményre lehet jutni (közös 
törvényhozás), és nem ellenségként viszonyulunk egymáshoz mind mikro-, mind makroszinten. Ezt követően van esély arra, hogy ilyenként lép fel majd a tagság (közvetve a munkavállalók) felé, intermedier szervezetként és privát törvényhozóként. Ha ma nem ilyen minden munkáltató, és nem ilyen minden szakszervezet, az a mi bününk is, alig tízmilliónké.

\section{Jegyzet}

${ }^{1}$ Sok helyen ez azt jelenti, hogy mi - vezetők, döntéshozók, HR-esek - természetesen fontosak vagyunk, és muszáj ide venni a pótolhatatlanokat is. A többi nem. Ezért nyílik a jövedelmi olló, ezért nem kell érdekképviselet.

\section{Felhasznált Irodalom}

Appelbaum, E. - Bailey, T. - Berg, P. - Kalleberg, A. L. (2000): Manufacturing advantage: Why highperformance work systems pay off. London: ILR Press

Bakacsi Gy. (2017): Mitől erős az alkupozíció? Vezetéstudomány, Vol. 48. No. 10., 2-9. o.

Bácsi K. (2017): Miért és mikor jó a bevonás? Érvek munkáltatói és munkavállalói oldalon. Vol. 48. No. 8-9., 13-21. o.

Botelho, C. (2017): The Role of Human and Social Capital on the Influence of HR Practices on Organizational Performance. Proceedings Of The European Conference On Intellectual Capital, 26-33. o.

Boxall, P. - Purcell, J. (2003): Strategy and human resource management. London: Palgrave Macmillan

Broughton, A. - Welz, C. (2013): Impact of the crisis on industrial relations. Dublin: European Foundation for the Improvement of Living and Working Conditions, Source: https://www.eurofound.europa. eu/observatories/eurwork/comparative-information/ impact-of-the-crisis-on-industrial-relations Retrieved: 20/02/2018

Donate, M. - Peña, I. - Sánchez de Pablo, J. (2016): HRM practices for human and social capital development: effects on innovation capabilities; International Journal of Human Resource Management, Vol. 27. No. 9., 928-953. o.

Drucker, P. F. (2003): Nem alkalmazottak, hanem emberek. Harvard Business Manager, 2003. januárfebruár, Vol. 5, No. 1., 20-27. o.

Juan, A. M. - Juan Martinez, T. (2016): Deconstructing AMO framework: a systematic review; Intangible Capital, Vol. 12. No. 4., 1040-1087. o.

Karoliny M. - Poór J. (szerk) (2017): Emberi erőforrás menedzsment kézikönyv. Budapest: Wolters Kluver
Karoliny M. (2009): Az értékteremtő HR-szervezetek. Vezetéstudomány, Vol. 40. No. 7-8., 11-23. o.

Kuvaas, B. - Buch, R. - Weibel, A. - Dysvik, A. - Nerstad, $C$. (2016): Do intrinsic and extrinsic motivation relate differently to employee outcomes? Journal of Economic Psychology, Vol. 61., 244-258. o.

László Gy. (1996): Szövetség a munkáért. Munkaügyi Szemle, No. 12., 10-15. o.

László Gy. (2002): Profitcélok és munkavállalói érdekek. Vezetéstudomány, Vol. 33. No. 7-8., 28-35. o.

László Gy. (2010): Alkalmazotti, foglalkoztatási vagy munkaügyi kapcsolatok? Munkaügyi Szemle, Vol. 54. No. 1., 33-41. o.

Lever-Tracy, C. (1984): The paradigm crisis of dualism: decay or regeneration? Politics and Society, Vol. 13., 59-89. o.

Meyer, J. P. - Becker, T. E. - Vandenberghe, C. (2004): Employee commitment and motivation: A conceptual analysis and integrative model. Journal of Applied Psychology, Vol. 89. No. 6., 991-1007 o.

Peck, J. A. (1989): Labour Market Segmentation Theory. Labour \& Industry: a journal of the social and economic relations of work, Vol. 2. No. 1, 119144 o.

Poór J. - Juhász T. - Szabó K. - Kovács I. É. - Karoliny M-né (2018): A külföldi tulajdonú vállalatok emberierőforrás-menedzselésének jellegzetességei és sajátos kontingenciafaktorai Kelet-Közép-Európában. Vezetéstudomány, Vol. 49. No. 1., 40-52. o.

Poór J. - Karoliny, M. - Kovács I. É. - Illés B. Cs. (szerk.) (é. n.): A HR gyakorlata. Budapest: Wolters Kluwers (megjelenés alatt)

Price, A. (2011): Human Resource Management. Donnelly: Cengage Learning EMEA

Sitar, A. S. - Mihelič, K. K. (2018): The Interplay of Expatriates. Psychological and Social Capital for Knowledge Transfer, Vol. 20. No. 2., 195-219. o.

Stuart, P. (1993): Labor unions become business partners/ Üzletpartnerré válnak a szakszervezetek. Personnel Journal, Vol. 72. No. 8., 54-63. o. Ism.: Ujfalussy Ö. (1994): Humánpolitikai Szemle No. 2., pp. 91-95.

Sweeney, B. - Curtarelli, M. - Aumayr-Pintar, C. Vargas Llave, O. - Cabrita, J. - Broughton, A. (2011): Industrial relations and working conditions developments in Europe 2010. Dublin: European Foundation for the Improvement of Living and Working Conditions.

Szőts-Kovács K. (2006): Merre tart az emberi erőforrás menedzsment? (Quo vadis HRM?) Vezetéstudomány, 37. évf., Különszám, 46-55. o. 